\title{
Participation in democratic Brazil: from popular hegemony and innovation to middle-class protest
}

Leonardo Avritzer

\section{Introduction}

Democracy has had historically different patterns of collective action (Tilly, 1986, 2007; Tarrow, 1996). Repertoires of collective action are a routine of processes of negotiation and struggle between the state and social actors (Tilly, 1986, p. 4). Each political era has a repertoire of collective action or protest that is related to many variables, among them the form of organization of the state; the form of organization of production; and the technological means available to social actors. Early eighteenthcentury France experienced roadblocks as a major form of collective action (Tilly, 1986). Late nineteenth-century France had already seen the development of other repertoires, such as the city mobilization that became famous in Paris and led to the re-organization of the city's urban spaces (Tarrow, 1996, p. 138-139).

At the same time that the French blocked roads and occupied cities, the Americans used associations and large demonstrations (Skocpol, 2001; Verba et al., 1994) to voice claims concerning the state. Particularly, in the twentieth century, the post-war movements engaged in the extensive use of demonstration and diffusion through technology for mobilization (Tarrow, 1996, p. 143). Thus, different societies in different contexts use associations and large demonstrations to mobilize for inclusion in the state. In the case of the United States, large demonstrations targeted electronic media, radio, and television outlets during the 60 s and $70 \mathrm{~s}$, betting that the media could play the role of increasing the impact of the demonstrations. In spite of large changes in the role of the media and the emergence of new electronic media and social networks such as Facebook and Twitter, the present work will argue that a similar configuration is taking place in Brazil.

Brazil has a very singular relation via-à-vis repertoires of collective action in Europe. The country has seen popular rebellions throughout the twentieth centuryinstances of revolt that ultimately failed to generate a democratic culture (Sevcenko, 1984). Important changes in the pattern of collective action took place during Brazil's democratization (Santos, 1993). The first important change was a rise and a change in the pattern of joining voluntary associations (Avritzer, 2000; Lavalle, 2011). There has been an increase not only in the number of people who joined such associations but also in the different types of associations that started to have more centrality in Brazil's political life, such as neighborhood associations or associations linked to the Catholic church. These associations were incorporated in hybrid forms of state and society interaction that are now called "institutional participation." This paper will show that 
PARTICIPATION IN DEMOCRATIC BRAZIL: FROM POPULAR HEGEMONY AND INNOVATION TO MIDDLE-CLASS PROTEST

because participation in associations that engaged in public activities was considered strong, the literature tended to downplay the role of more conservative private associations. I analyze here the recent change in the pattern of mobilization in Brazil and show that said change is strongly tied to changes in the pattern of association. Until 2013, Brazil diverted from the North American pattern of association, a pattern that shows a clear hegemony of middle-class actors at different venues for participation (Verba et al., 1995). Only after this change have we seen a "normalization" of the pattern of participation in the country. In the paper, I will first explain this process of change in pattern of association and later try to analyze the effect of these changes on the June 2013 demonstration. These demonstrations still demand an explanation. I will show that there are two available explanations for the June 2013 demonstrations: an external line of explanation based on the willingness of members of charities, clubs, and professional associations to go public; a second explanation points to the inability of the movement that initially called the demonstrations the Free Pass Movement (MPL) to politicize it. I will synthesize these two explanations in order to provide a broader one that takes into account changes in pattern of association and collective action.

\section{Institutional participation as a repertoire of collective action}

Brazil has experienced changes over the last 30 years that have significantly altered the political and social organization of the country. First, democracy was reestablished in 1985 and the Constitution followed in 1988. The Constitution introduced two important changes for Brazil: the first concerns the system of political representation. The post-1988 system of political representation in Brazil maintains the wide prerogatives of the President and incorporates them into a system of inter-party negotiations within the National Congress. Discipline, in terms of political support for the President, is achieved through a system of institutionalization of give-and-take politics. Although this system has a high rate of success of presidential initiatives-close to that of the British parliamentary system (Limongi, 2006, p. 6)-most of the resources involved in MP's amendments or political indications are spent irrationally and have led to corruption among the governing coalition (Ames, 2002, p. 22-23). In this sense, the system of representation has experienced both innovation and fragmentation, simultaneously allowing governance in terms of the approval of executive branch proposals in Congress and generating un-governability in terms of the wide rejection of these practices by public opinion that has increased dramatically since 2013.

The second change to follow the Constitution was a dramatic increase in participation. Due to regulations outlined within the Constitution, during the $1990 \mathrm{~s}$, more than 10,000 local councils were created in Brazil spanning the areas of health, social assistance, and urban planning. Outlined within the Constitution chapter regarding social assistance were the Lei Orgânica da Saúde (LOS), Lei Orgânica da Assistência Social (LOAS), and the Statute of the City of 2000. The focus of these regulations is to 
introduce new participatory mechanisms and participatory institutions at both the local and national level. These councils are hybrid participatory formats in which civil society associations elect, or otherwise, choose members of their constituencies to participate. In policy councils, civil society actors share decision-making with state actors within a common decision-making framework. Today in Brazil, there are close to 5,000 health councils, 5,000 social assistance councils, and 1,000 participatory city master plans (Avritzer, 2009, p. 116).

Social participation in Brazil after 1988 is both an institutional policy and a repertoire of collective action. As an institutional policy, it incorporates social actors in decision-making processes in areas as important as health and social protection. As a repertoire of collective action, institutional participation integrates into decision-making processes new actors who join neighborhood associations and associations linked to health issues or to education, among others (Avritzer, 2002; Baiocchi, 2005; Wampler, 2007; Avritzer, 2009; Wampler, 2015). This has generated a long process of inclusion and reduction of inequalities in Brazil, changing a previous pattern of exclusion of the poor by the political system that prevailed until 1985 .

The inauguration of Luiz Inácio Lula da Silva as president of Brazil in January 2003 is a second moment that greatly influenced the nature of social participation in the country. Brazil has two main institutions that help the president in his/her relation with the political system. The first, "Casa Civil," is the equivalent to the chief of staff, and the second, is the general secretary of the presidency that until 2002 had attributions linked to the specific needs of MPs (most of them linked to pork politics). During Lula's first day in office, he altered the role of the general secretary by assigning to the secretary the duty of coordinating relations with civil society actors (Brazil, law decree 4570). In addition, many new national councils were introduced in areas of both social and public policy. In fact, the number of national councils increased from 15 to 31 councils during Lula's first term in office.

More significantly, however, it was through national conferences that social participation acquired a new role in the federal government in Brazil. National conferences are large public meetings between state and civil society representatives that make proposals for the implementation of specific public policies. National conferences have taken place in Brazil since the 40s when President Getúlio Vargas carried out the first national conference on health. Between 2003 and 2010, the federal government organized 74 national conferences. Twenty-three new conferences were organized between 2011 and 2012. These conferences played the role of connecting civil society with the government, offsetting the lack of legitimacy of the political system in the eyes of civil society. Again, it is possible to argue that, just as at the local level, changes in the pattern of collective action impact the state and democracy at the national level. New venues for social inclusion were opened at the state level with the participation of social actors. This drive has generated a decrease in inequality. 
Since 2013, Brazil has been experiencing changes in both levels of participation and levels of representation. As regards representation, the strengthening of conservative forces in Congress is taking place because of a huge increase in private financing. According to the data of the Movimento Nacional de Combate a Corrupção Eleitoral, among the 500 best financed campaigns in Brazil, more than 300 have been successful in electing MPs. Money has become the decisive factor in the composition of the National Congress, moving it to assume a conservative stance. Additionally, other factors have contributed to this rightward shift: (1) the reaction against the legalization of civil rights for the gay population; (2) being against the stabilization of public finances; and, last but not least, (3) strongly reacting against the increase in participation at the federal level embodied in decree 8243. Thus, in spite of an important increase in participation at the federal level, there is a strong reaction against participation at the law-making level. We are also seeing that participation alone cannot change the composition of the system of representation.

The events occurring in Brazil in June of 2013-events that changed the pattern of social participation-have called the world's attention. At the time, the infrastructure works for the World Cup and concerns over public transportation were high on the agenda. Members of left-wing sectors were dissatisfied with Dilma's government and their approach to urban politics (Maricato, 2013), which consequently catalyzed strong right-wing dissatisfaction with the government. When we look at the demonstrations taking place and the participants, it was mainly young people pushing the agenda ( $43 \%$ were between 14 and 24 years old). These youths can be further characterized by their high levels of education ( $91 \%$ were in college or had finished college) and high incomes ( $23 \%$ had family incomes equivalent to more than ten minimum wages) (Avritzer, 2015). June 2013 initiated a movement that started with a fissure within the participatory field hegemonized by the Workers Party since the beginning of democratization in 1985 and evolved into a strong polarization in the participatory field. Such polarization continued through 2014 and was broken in the March 2015 demonstration when middle class opposition assumed control of the participatory field in Brazil. In the next section of this paper, I will show how this change took place and will propose a model for understanding its political consequences.

\section{Participation in Brazil from 2003 to 2013: from social movements and state synergy to sharp opposition}

Participation at the national level in Brazil is a new phenomenon that resulted from the architecture of the 1988 Constitution. This architecture itself followed from the changes in the repertoire of collective action at the beginning of democratization. At the beginning of the 90s, participation was still relatively weak as the new national conferences in the areas of health and social assistance were institutionalized (Avritzer, 2009). However, in just a few years, a first row of national council emerged in the wake 
of several different legislations on social participation, such as LOS, LOAS, the Statute on Children and Teenagers, and the environmental law. Yet, it was only after the beginning of Lula's first administration that social participation at the national level really picked up momentum, an indication that the new repertoire of collective action has had societal and political components. Both the number of national conferences (74 between 2003 and 2010) and the number of participants increased sharply under the leadership of Lula's government. In a survey applied in a national sample of 2,200 randomly selected individuals ${ }^{1}$, respondents were asked about their pattern of participation. Still, religious participation was the highest, but professional associations, trade unions, and participatory institutions (43\%) are also noteworthy.

Table 1

Pattern of participation of the Brazilian population in 2010 (\%)

Did you participate in one of the spaces below?

\begin{tabular}{|l|c|c|c|}
\hline & \multicolumn{3}{|c|}{ Conferences } \\
\hline Participatory budgeting & Participated & Did not participate & NR \\
\hline Neighborhood association & 3 & 96,9 & 0,05 \\
\hline Sport clubs & 7,3 & 92,6 & 0,09 \\
\hline Thematic NGOs & 6,3 & 93,6 & 0,05 \\
\hline Professional associations & 3,1 & 96,9 & 0,05 \\
\hline Church or religious organization & 4,8 & 95,1 & 0,05 \\
\hline Charity association & 13,1 & 86,8 & 0,05 \\
\hline PTAs & 7,8 & 92,2 & 0,05 \\
\hline Municipal councils & 5,8 & 94,1 & 0,05 \\
\hline Regional councils & 1,4 & 98,6 & 0 \\
\hline Public policy councils & 0,7 & 99,3 & 0 \\
\hline Political party & - & - & - \\
\hline Trade union & 4,1 & 95,9 & 0 \\
\hline Total belonging to associations & 4,3 & 95,7 & 0 \\
\hline Political parties and trade unions & 23 & 77 & 0 \\
\hline Participatory institutions & 7,5 & 92,5 & 0 \\
\hline Source Avitzr, 2013. & 4,3 & 95,7 & 0 \\
\hline
\end{tabular}

Source: Avritzer, 2013.

\footnotetext{
1 The survey represents a partnership between UFMG and Prodep. 2,000 questionnaires were applied to a randomly selected sample. The sample is representative of all regions of Brazil and the state of São Paulo. The question whose answers are presented in the table below is: "I will read a list of activities and would like to know if you have participated in them in any way during the last two years." For more details on the sample, see Avritzer (2004).
} 
Table 1 depicts a moment in the rise of popular and institutionalized participation in Brazil in 2010. Affiliation in neighborhood associations ranks high, followed by affiliation to school councils, professional associations and, last but not least, religious associations. All these forms of participation have made Brazil a country with a participatory civil society characterized by a strong synergy between civil and political groups (Baiocchi, 2005). The socio-economic profile of the participants does not dictate people's participation. Members of both local and national participatory experiences shared many profile elements, such as income (between 1 to 5 minimum wages) and average years of education ( 8 years) (see Table 2 ). Thus, the pattern of social participation in Brazil from 1985 to 2013 can be established: re-enforced selected civil associations with strong political links with institutional participation. In terms of its social configuration, a pattern is also observed: participants' incomes are very close to the Brazilian average and levels of education are slightly higher.

Table 2

Social actors in the different forms of social participation in Brazil

\begin{tabular}{|c|c|c|c|}
\hline $\begin{array}{c}\text { Participation in PB } \\
\text { national } \\
\text { conferences }^{2} \text { and } \\
\text { June } \\
\text { demonstrations }\end{array}$ & $\begin{array}{l}\text { Average income of } \\
\text { the participants }\end{array}$ & $\begin{array}{c}\text { Average years of } \\
\text { education of the } \\
\text { participants }\end{array}$ & Gender \\
\hline $\begin{array}{c}\text { PB in Porto Alegre } \\
(1998)\end{array}$ & $\begin{array}{l}2 \text { to } 5 \text { minimum wages } \\
(34.4 \%)\end{array}$ & $\begin{array}{l}\text { up to } 8 \text { years of } \\
\text { education }(46.1 \%)\end{array}$ & $\begin{array}{c}51.4 \% \text { of the } \\
\text { participants are } \\
\text { women }\end{array}$ \\
\hline $\begin{array}{c}\text { National conferences } \\
\text { (2010) }\end{array}$ & $\begin{array}{l}1 \text { to } 4 \text { minimum wages } \\
(52.2 \%)\end{array}$ & $\begin{array}{c}\text { minimum wages } \\
(38.1 \%)\end{array}$ & $\begin{array}{c}51.2 \% \text { of the } \\
\text { participants are } \\
\text { women }\end{array}$ \\
\hline $\begin{array}{c}\text { June } 2013 \\
\text { demonstrations }\end{array}$ & $\begin{array}{l}\text { More than } 10 \\
\text { minimum wages }\end{array}$ & $43 \%$ completed college & $\begin{array}{c}50 \% \text { of the } \\
\text { participants are } \\
\text { women }\end{array}$ \\
\hline
\end{tabular}

Source: Avritzer, 2002, 2013.

Participation successfully improved relations between social actors and government, especially at the federal level between 2003 and 2013. National conferences and participation at the national level have provided an excellent way out of the problems the PT was facing in Congress. National conferences created strong consensus between state and civil society in key areas of social policy after 2005. In areas such as health, social assistance, food security, urban policy, women's issues (assuntos das mulheres), we can see today the formation of a joint agenda between state and civil society. In most of the areas of social policy, the Brazilian federal government has been able to establish a joint agenda with civil society actors, facilitating both the building of consensus on

\footnotetext{
${ }^{2}$ An anonymous reviewer pointed out that there is evidence of stratification for the participants of national conferences. Our data is mixed in this regard. When we analyze participation in all stages of the national conferences, we do not see stratification. Stratification in terms of income and education appears in regard to national level participants.
} 
policies at the federal level ${ }^{3}$ and in the approval of national conferences proposals in Congress. SUAS (the national social assistance system) and SISAN (national system on food security) are excellent examples of the new capacity of the federal government to get fast approval of legislation in Congress.

Although these elements are important advances in the establishment of a political relation between the federal government and Congress, national conferences alone cannot account for all aspects of the political relationship between the two branches of government. Throughout the whole 2003-2013 period, the composition of the National Congress became more conservative, and the pork barrel negotiations and give-and-take processes in the appointment of ministries became highly challenged at the public opinion level. Thus, the partial success of participation between 2003 and 2013 can be explained by the following conditions: (1) previous local traditions of participation that the Workers Party could draw upon; (2) available actors that immediately engaged in the participatory process; (3) the government was willing to carry out participatory results at the level of social policies; and (4) Congress remained neutral in relation to the evolvement of the participatory process. Together, these four elements explain a successful repertoire of participation and the resulting process of political inclusion.

All these conditions changed after June 2013 when sectors politically to the left of the PT and of Dilma's government began to rally as a challenge to urban policies and a break with the historical compromises around urban rights included in the "World Cup Law." These social actors had a history of acting in a few cities, like Salvador and Florianópolis, on issues such as increases in bus fare. These sectors had been mobilizing since April 2013, but a harsh repression of a demonstration against an increase in bus fares in São Paulo on the $7^{\text {th }}$ of June 2013 was the catalyst that altered their mobilization efforts and the scale of the movement. Huge demonstrations in Rio de Janeiro, São Paulo, and Belo Horizonte followed-each one attended by hundreds of thousands of people. In Brasília, demonstrators occupied the ramp of the National Congress.

These demonstrations went on for three weeks and, consequently, these they changed the participatory pact that had been enforced in Brazil since 2003. Two critical junctures mark June 2013. The first one, as mentioned earlier, was the change in the pattern of participation post-democratization. When we look into the organization of the social movement and the Internet in early June 2013, we clearly see a hegemony of the MPL. The MPL network, which is described below ${ }^{4}$, has had more followers than any of the other large networks. The large stains in the Figure 1 represent likes and shares of the demonstration called by MPL in June. However, if we analyze the expression of support of the MPL page in June, we see that the page primarily concentrated on issues

\footnotetext{
3 In its interview with managers of federal government programs, Ipea asked them what participation helps. They answered that participation helps in building consensus on policies at the federal level. See Sousa \& Pires (2012).

${ }^{4}$ Internet data collection was carried out using the software Netvizz as well as Netlytic. Netvizz has been used to extract data about the Facebook profiles of the MPL during the month of June 2013. After the data extraction, we hierarchize posts according to shares and likes.
} 
linked to public transportation. The five most liked or commented posts included: the institutional notes of the movement on the demonstrations such as the photo of June $18^{\text {th }}$ demonstration with 14,356 likes and note 11 issued on June $20^{\text {th }}$, with 9989 likes. The demonstration to commemorate the revocation of the fare hike in São Paulo had 13,858 likes. There is a common trace to the ten most liked/commented posts of the MPL during the month of June 2013. All the posts are about a social movement, in this case a movement against the fare hike. There are no posts on broader issues such as corruption or the political system.

\section{Figure 1}

MPL posts and network on the Internet

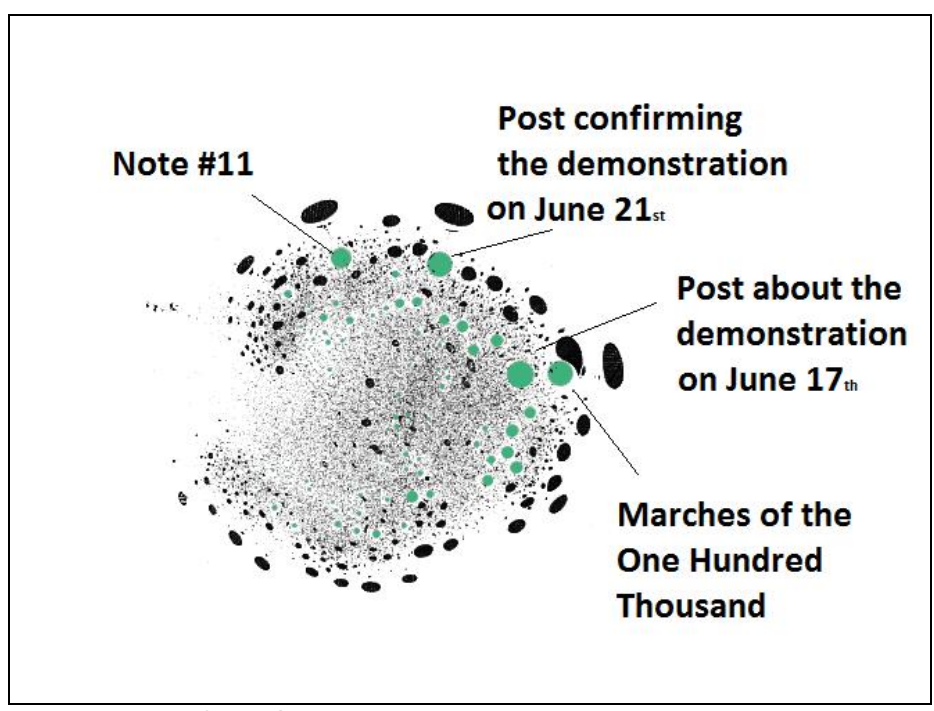

Source: Own formulation.

Nevertheless, if we look closer into the influence of MPL in the agenda of the demonstrations, we start to see already in June 2013 a split in the organization of public opinion. This split took place among right and left themes and, as I will show below, marks the beginning of a new organization of conservative public opinion and social networks in Brazil after 2013.

Still during the month of June, conservative profiles acquire a new strength on social networks. The most important aspect of this element of strengthening was the creation of new profiles, such as the MBL's (Movimento Brasil Livre) in June. The MBL network would become one of the strongest elements of the new conservative movement in Brazil during 2014 and 2015. Immediately, it started a process of differentiation within the demonstrators' field. This process expanded the concerns of demonstrators from the political system to the issue of corruption and started to single out the PT and the government as a source of corruption. Figure 2 below represents the Facebook profile of the MBL page in its first month of operation (June 2013). The most liked posts were, first 
of all, about following the page; second a new photo on the page, and third and fourth, posts targeting the issue of corruption within the political system.

Figure 2

MBL post and traffic on the Internet

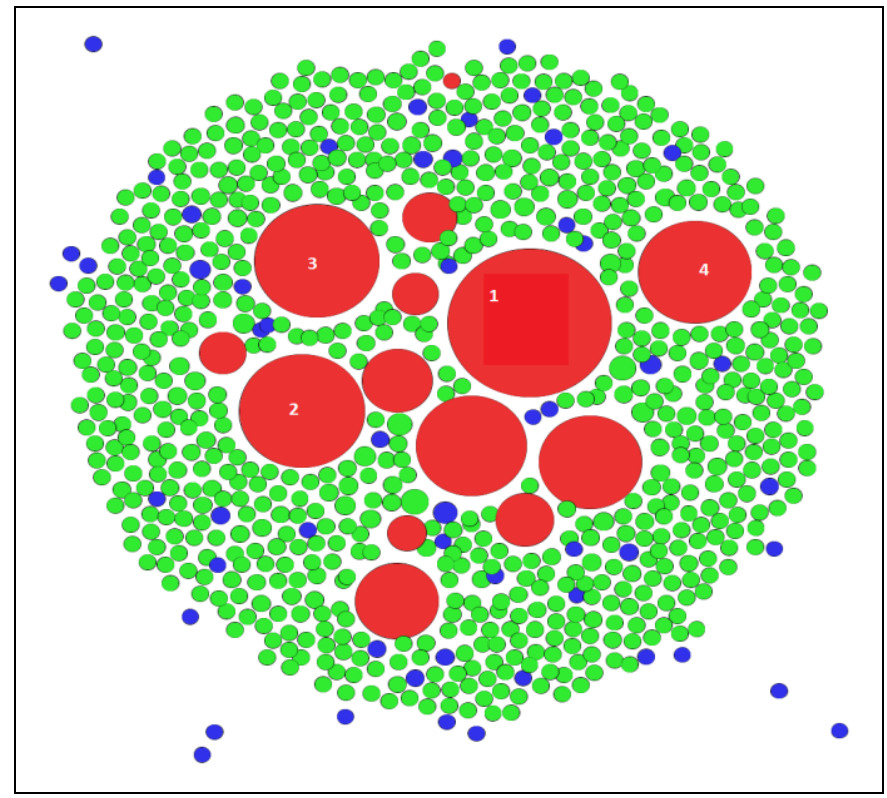

Source: Own formulation

Hence, what we can see is that June 2013 opened the way for a re-organization of conservative sectors in Brazil, first on the Internet and later on the streets ${ }^{5}$. This reorganization took place in several stages. The first stage was the differentiation of agendas within the demonstrators' field. This process, as I have shown, involved two integrated actions: the first one was the thematic pluralization of the demonstration's claims, which was more than natural given the diversity of the actors involved. This pluralization is clearly shown in Causa Brasil maps of Internet posts (Avritzer, 2016). In these maps we can see that June 2013 started with an agenda on the Internet around the free pass and the fare hike in São Paulo and in three weeks moved to the issues of approval of Dilma's government and the targeting of political corruption. However, the

\footnotetext{
${ }^{5}$ An anonymous reviewer of this paper claimed that our analysis of the June 2013 events as having been seized by conservative groups lacks empirical grounding. He or she provides as counterevidence the fact that $21 \%$ of the protesters identified with the PT, PV, or PSOL, leftist parties in Brazil. I believe the data presented by the reviewer is partial even for 2013. Though it is clear that many supporters of the PT and other parties have had a meaningful presence at the June 2013 demonstrations, there is also empirical data that shows that a significant number of conservative actors were also there. In a survey applied at São Paulo's conservative demonstration on August 16, 2015, 54.8\% of the demonstrators acknowledged their presence in the 2013 demonstrations. They identified themselves as conservatives on issues such as dissatisfaction with Brazilian democracy, assigning little importance to social policy, and supporting the state government in São Paulo.
} 
second step was more politically meaningful. It involved the creation of conservative profiles that would initially present issue of corruption and subsequently narrow in on the issue of corruption in government. In the next section of this paper, I will show the operation of this strategy.

\section{The polarization of the participatory field in Brazil after 2013}

During June 2013, a watershed in social participation in Brazil took place. The participatory field constructed by progressive social actors and the Workers Party initially pluralized with the participation of middle-class social actors. The pattern of participation continued to change throughout the next few years, including a division of middle-class actors during the 2014 elections (according to Datafolha). The old and new middle-class divided, and the new middle-classes' support for the PT, though short-lived, was decisive for its electoral victory (Avritzer, 2015). In March 2015, less than 90 days after the inauguration, middle-class protesters were back on the streets, but with a change in grievance. The main claim was the impeachment of the President.

A survey ${ }^{6}$ applied among the protesters in Belo Horizonte, Brasília, and São Paulo inquired into the social characteristics of the protesters. As regards income and education, the results showed that $46 \%$ of the protesters in Belo Horizonte had income above 10 minimum wages. In Brasília the average income is even higher (49\%), and in both cities more than $80 \%$ of protestors had a college education (Avritzer, 2015). The highest income profile was found in São Paulo where $52 \%$ of demonstrators had an average income above 10 minimum wages. However, the most interesting findings concern the pattern of participation of the protesters. The survey showed a history of previous participation in both participatory budgeting and neighborhood associations similar to that of participatory groups researched on PB. (Wampler \& Avritzer, 2004). If we compare participation at national conferences with participation in the demonstrations in Belo Horizonte, Brasília, and São Paulo, we see high levels in both settings and participant crossover. Among national conference participants, $17.5 \%$ participated in PB, and $20.5 \%$ of Belo Horizonte's demonstrators participated in PB in Belo Horizonte, whereas only $8.5 \%$ participated in São Paulo. The data for Belo Horizonte is high for obvious reasons: The city has had participatory budgeting for almost 20 years with high levels of participation, making it likely that a large share of the city's population could have participated in PB. The data for Brasília and São Paulo seem to confirm our hypothesis: only $12.4 \%$ of the demonstrators participated in PB at some point.

However, the data that seems most important regards recreational and professional associations: we see very high levels of participation both in the case of Belo

\footnotetext{
${ }^{6}$ We applied surveys in the demonstrations of April 15 in Belo Horizonte and Brasília and August 16 in the São Paulo demonstrations. The number of questionnaires applied was 486 . We applied the questionnaires trying to adopt diverse criteria, interviewing young and old, black and white, and male and female participants.
} 
Horizonte and Brasília. In regards to sport clubs or recreational associations, $37.8 \%$ of respondents in Belo Horizonte and $51.4 \%$ in Brasília acknowledged participation. For professional associations, $51.3 \%$ of respondents in Belo Horizonte and $57.1 \%$ in Brasília acknowledged their participation. Regarding charity associations, 51.1\% acknowledged their participation in São Paulo, 57.5\% in Belo Horizonte, and $64.8 \%$ in Brasília. Finally, it is important to look at the data on political party affiliation, which is high in Belo Horizonte and very high in Brasília. Thus, we can conclude that we are not talking about a group that does not have a participatory background; rather, we are talking about one with a participatory background different from the traditional pattern of social participation in Brazil. Participants are aware of the venues for social participation that divert from the traditional pattern of social participation in Brazil. Participants have a tendency to participate more intensely in clubs and charity organizations even if they also joined participatory institutions.

Table 3

Demonstrator's participation in voluntary associations in 2015

Did you participate in some of the spaces below?

\begin{tabular}{|l|c|c|c|c|c|c|c|c|c|}
\hline & \multicolumn{2}{|c|}{$\begin{array}{c}\text { Demonstrations - Belo } \\
\text { Horizonte }\end{array}$} & $\begin{array}{c}\text { Pemonstrations - Brasília } \\
(\%)\end{array}$ & $\begin{array}{c}\text { Demonstrations - São } \\
\text { Paulo }\end{array}$ \\
\hline $\begin{array}{l}\text { Participated } \\
\text { partipate }\end{array}$ & $\begin{array}{c}\text { NR } \\
(\%)\end{array}$ & $\begin{array}{c}\text { Participated } \\
(\%)\end{array}$ & $\begin{array}{c}\text { Did not } \\
\text { participate } \\
(\%)\end{array}$ & $\begin{array}{c}\text { NR } \\
(\%)\end{array}$ & $\begin{array}{c}\text { Participated } \\
(\%)\end{array}$ & $\begin{array}{c}\text { Did not } \\
\text { participate } \\
(\%)\end{array}$ & $\begin{array}{c}\text { NR } \\
(\%)\end{array}$ \\
\hline $\begin{array}{l}\text { Participatory } \\
\text { budgeting }\end{array}$ & 20.7 & 77.7 & 1.6 & 12.4 & 76.2 & 11.4 & 8.5 & 90.4 & 0,5 \\
\hline $\begin{array}{l}\text { Neighborhood } \\
\text { association }\end{array}$ & 26.4 & 73.6 & 0 & 28.6 & 66.7 & 4.8 & 23.4 & 76.6 & 0 \\
\hline Sports club & 37.8 & 62.6 & 0 & 51.4 & 45.7 & 2.9 & & & 0 \\
\hline $\begin{array}{l}\text { NGOs and } \\
\text { thematic } \\
\text { associations }\end{array}$ & 20.7 & 77.7 & 1.6 & 29.5 & 68.6 & 1.9 & 19.7 & 80.3 & 0 \\
\hline $\begin{array}{l}\text { Professional } \\
\text { associations }\end{array}$ & 51.3 & 48.2 & 0.5 & 57.1 & 41 & 1.9 & 43.1 & 56.9 & 0 \\
\hline $\begin{array}{l}\text { Church and } \\
\text { religious } \\
\text { organizations }\end{array}$ & 40.4 & 59.1 & 0.5 & 47.6 & 52.4 & 0 & 31.9 & 68.1 & 0 \\
\hline $\begin{array}{l}\text { Charity } \\
\text { associations }\end{array}$ & 57.5 & 42 & 0.5 & 64.8 & 34.3 & 1 & 51.1 & 48.9 & 0 \\
\hline PTA & 28.5 & 71 & 0.5 & 25.7 & 70.5 & 3.8 & 14.9 & 85.1 & 0 \\
\hline
\end{tabular}

Source: Avritzer (2015). 
PARTICIPATION IN DEMOCRATIC BRAZIL: FROM POPULAR HEGEMONY AND INNOVATION TO MIDDLE-CLASS PROTEST

Last but not least, there seems to be a difference between the demonstrators in Belo Horizonte and Brasília. Brasília shows the pattern of participation of a city without strong forms of institutionalized participation, whereas Belo Horizonte bridges both institutional and non-institutional participation. It is difficult to say at this point what the national standard is, but such information may emerge from a survey we conducted this past August in São Paulo.

\section{Understanding the change in the pattern of participation in Brazil}

Brazil's pattern of participation diverted from that of many other countries between 1985 and 2013. It is well known that the pattern of participation in the United States and countries such as Italy is dominated by the middle-class (Verba, 1995; Putnam, 1993, 2000). This pattern does not lead to direct political participation, but it has a political impact and allows conservative sectors to enhance their political influence. For example, the uneven financing of public education in the United States expresses middle-class activism in the country as well as the financing of culture. On the other hand, the sub-financing of inner cities is also related to the low brokerage power of popular sectors in the United States. Brazil has diverted from this pattern of participation both because it has had a long cycle of participation centered on poor social actors because the public belonged to a certain type of public/political association. Thus, the analysis presented here is different from the data presented by Ribeiro and Borba (2015); it focuses on different types of associations as having different political consequences (Krishna, 2000).

In contrast, between 1985 and 2013, Brazil developed a pattern of participation that concentrated on generating participation among the poor through avenues like participatory budgeting and national conferences. In both of these cases, there is both a repertoire of contention and a pattern of participation that involves those with income between one and five minimum wages with up to eight years of education. This participation contrasts with the pattern of participation extant in the Northern democracies, not only due to its participants, but also due to its relations with the political system. Participation in Brazil after 1990 meant institutional participation, and it helped establish a participatory project (Dagnino et al., 2008) through which the government initiated participation and social actors joined the process, thus strengthening participation as a whole. As a result of this process, Brazil sees a boost in the distributive social policies sponsored by the state both at the local and federal levels of government, as shown in Figure 3. 
Figure 3

Participatory project from 1985 to 2013

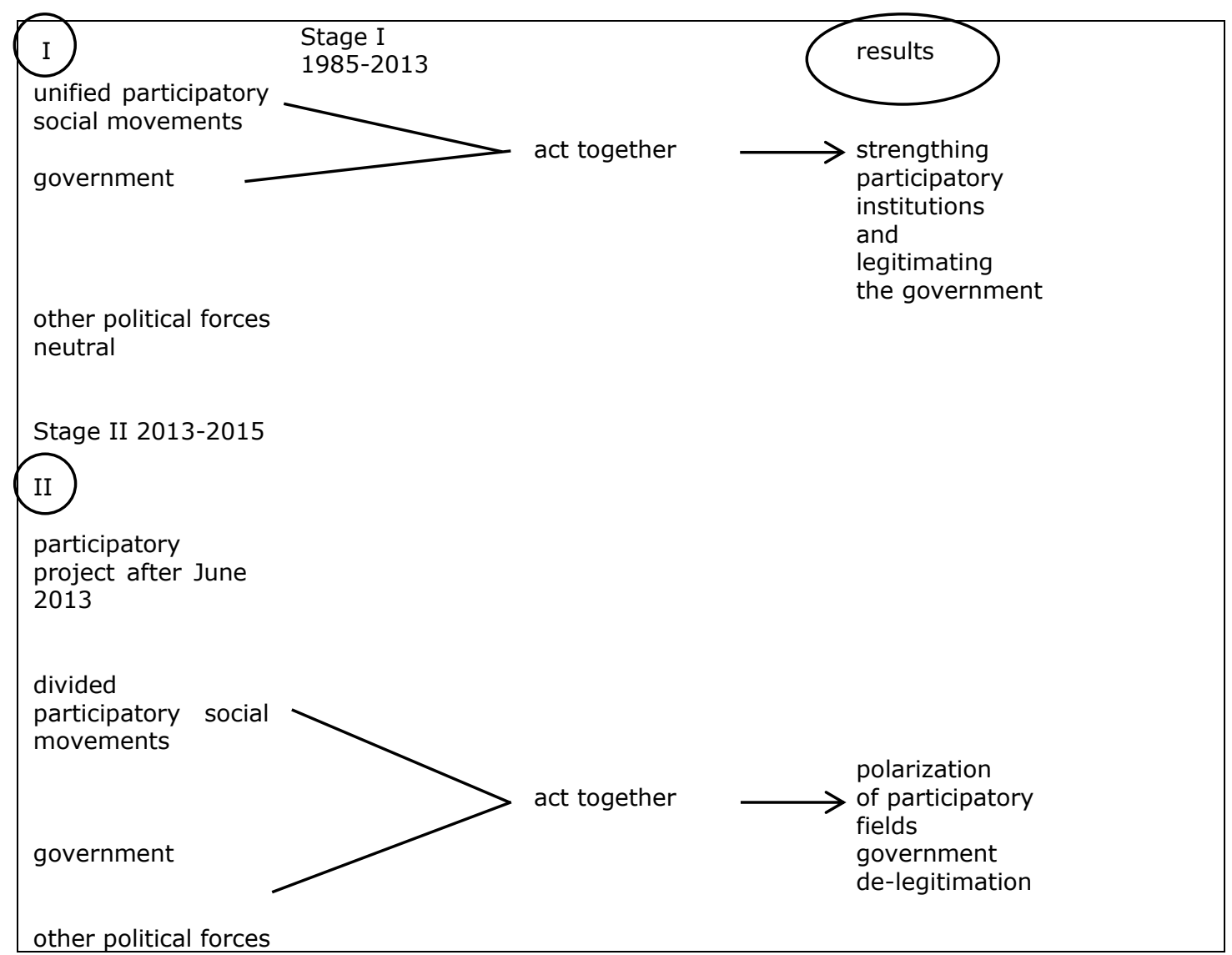

Source: Own formulation.

Social participation, in the form described in section one, was naturalized in Brazil until 2013, in the sense that much of the literature assumed that participation in the country would sustain these characteristics, namely that of a booster of state and popular civil society (Avritzer, 2009; Lavalle, 2011; Tatagiba, 2015;). It was assumed that the configuration of social participation in democratic Brazil would be the one instituted in 1985. However, in June 2013 a second period opened up in which participation took a different configuration. This had been a gradual process: first the participatory pole was pluralized, and later it has seen a split between progressive and conservative forces. Finally in 2015, Brazil has seen the hegemony of the participatory 
PARTICIPATION IN DEMOCRATIC BRAZIL: FROM POPULAR HEGEMONY AND INNOVATION TO MIDDLE-CLASS PROTEST

field by conservative sectors (see Figure 3). Altogether, the new forms of public protest mark the change in the repertoire of collective action.

Since June 2013, and especially after 2014, a new pole emerged in social participation. This pole was formed by a middle-class who had previously been a secondary part of participatory policies, as data corroborated by the level of participation in PB and neighborhood associations show. However, this group expresses a different pole because its center has never been participatory policies but rather participation in charities and professional association, as the above data show. The entrance of this group into participation split the participatory field. The Brazilian opposition forces, in particular the PSDB, have been aloof from social participation since the early 90s. However, there is a new (post-2013) movement of reconnection between the opposition and these forces. It has changed the configuration of participation from model I to model II. In model two, participation is an extra-institutional tool for the process of equilibrium among important political forces. The capacity of the PT to anchor itself in the streets was reduced by this new configuration, which in turn facilitated the impeachment of president Dilma Rousseff.

It is impossible to forecast if there will be a stage III-that will more likely be a consequence of strong polarization with both the progressive and the conservative side mobilizing. What is possible to say is that the anchorage that social participation afforded the PT's governments is over, and right now the movements on the streets are only making the government more unstable. However, it is likely we are arriving at some closure related to the specific configuration of social participation that emerged from the "new republic", not only in the area of participation, but also at the level of representation. What will emerge in its place? It is too soon to tell. The only conclusion reached, thus far, is that a form of social participation such as the one Brazil has known after 1985 is more the international exception than the rule. Now Brazil is having a normalization of participation that shows that it can play both a stabilizing and a destabilizing role. The specific configuration that made the Brazilian case a successful participatory case may now be over.

Leonardo Avritzer - Professor at the Political Science Department of the College of Philosophy and Human Sciences at the Federal University of Minas Gerais. Coordinator of the Participatory Democracy Project. E-mail: <avritzer1@gmail.com>.

\section{Bibliographical references}

AMES, B. The deadlock of democracy in Brazil: interests, identities, and institutions in comparative politics. Ann Arbor: University of Michigan Press. Brazilian Edition FGV, 2001.

Avritzer, L. Democracy and the public space in Latin America. Princeton: Princeton University Press. 2002. 
AVRITZer, L. A participação em São Paulo. São Paulo: Editora da Unesp, 2004.

AVRITZER, L. "Instituições participativas e desenho institucional: algumas considerações sobre a variação da participação no Brasil democrático". Campinas, Opinião Pública, 14(1), 43-64, 2008a.

AVRITZER, L. "Sociedade civil, instituições participativas e representação: da autorização à legitimidade da ação". Dados, vol. 4, n 47, 2008b.

Participatory institutions in democratic Brazil. Washington: Wilson Press/Johns Hopkins University Press, 2009.

. A dinâmica da participação local no Brasil. São Paulo: Cortez, 2010.

. Conferências nacionais: ampliando e redefinindo os padrões de participação social no Brasil. In: AVRItZer, L; SouzA, C. Conferências nacionais: atores, dinâmicas participativas e efetividade. Brasília: Ipea, 2013.

. "Middle class participation in Brazil". In: Anais APSA, San Francisco, 2015.

. Impasses da democracia no Brasil. Rio de Janeiro: Civilização Brasileira, 2016.

BRAzIL. Law decree 4570. General Secretary of the Presidency. Brasília.

BAIocchI, G. Militants and citizens: the politics of participatory democracy in Porto Alegre. Stanford: Stanford University Press, 2005.

DAGNino, E., et al. La disputa por la construción democrática en América Latina. México. Fundo de Cultura, 2008.

DataFolha. Pesquisa sobre intenção de voto para presidente em setembro. São Paulo, 2014.

HARVEY, D; MARICATO, E. Cidades rebeldes: o movimento passe livre e as manifestações que tomaram conta do Brasil. São Paulo: Boitempo, 2013.

KRISHNA, A. Active social capital. New York: Columbia University Press, 2000.

LAVAlLE, A. Participação: valor, utilidade, efeitos e causa. In: PIRES, R. A efetividade das instituições participativas no Brasil: estratégias de avaliação, vol. 7, Brasília: Ipea, 2011.

LIMONGI, F. Presidencialismo, coalizão partidária e processo decisório. Novos Estudos - Cebrap, nº 76, 2006.

PIRES, R. R.; SOUZA, C. "Conferências nacionais como interfaces socioestatais: seus usos e papeis na perspectiva dos gestores federais". Revista do Serviço Público, Brasília, vol. 63, n 4, 2012.

Putnam, R. D. "The prosperous community". The American Prospect, 4(13), p. 35-42, 1993.

. Comunidade e democracia: a experiência da Itália moderna. FGV Editora, 2000.

Ribeiro, E.; BorbA; J. "Protesto político na América Latina". Opinião pública, Campinas, vol. 21, nº $1,2015$.

SANTOS, B. D. S. Towards a new common sense: law, science and politics in the paradigmatic transition. New York: Routledge, 1995.

SeVECENKo, N. A revolta da vacina: mentes insanas em corpos rebeldes. São Paulo: Brasiliense, 1984.

Skocpol, T. Diminished democracy: from membership to management in American civic life. Norman: University of Oklahoma Press, 2001. 
PARTICIPATION IN DEMOCRATIC BRAZIL: FROM POPULAR HEGEMONY AND INNOVATION TO MIDDLE-CLASS PROTEST

TAtAgibA L., et al. "Balanço dos estudos sobre conselhos de políticas na última década". Lua Nova, São Paulo, n 95, 2015.

TARRow, S. Power in movement. Cambridge: Cambridge University Press. 1996.

TILLY, C. The contentious French: four centuries of popular struggle. Cambridge: Harvard University Press, 1986.

. Tilly, C. Democracy. Cambridge: Cambridge University Press, 2007.

Verba, S.; Schlozman, K. L; Brady, H. E. Voice and equality: civic voluntarism in American politics. Cambridge: Harvard University Press, 1995.

WAMPLer, B. Participatory budgeting in Brazil: contestation, cooperation and accountability. University Park: Penn State University Press, 2007.

. WAmpler, B. Activating democracy in Brazil. Notre Dame: Notre Dame Press, 2015.

WAMPLER, B.; AVRITZER, L. "Participatory publics: civil society and new institutions". Journal of Comparative Politics, New York, 2004.

\begin{abstract}
Participation in democratic Brazil: from popular hegemony and innovation to middle-class protest
\end{abstract}

Brazil became a reference case of social participation after the success of participatory budgeting during the early 90 s. The standard theory of the success of participation points to its positive impact on the political system. However, since 2013 Brazil has been experiencing some important changes regarding both participation and representation. In regard to representation, the strengthening of conservative forces in Congress is taking place because of a large increase in private financing. We are also seeing that participation alone cannot change the composition of the system of representation. The events that occurred in Brazil in June 2013, which led to changes in the patterns of social participation, have attracted attention worldwide. The aim of this paper is to analyze these changes in Brazil and point out how they influenced the country's political system and impacted the organization of Brazilian democracy. The data show how MPL presented its demands without politicizing them, keeping itself a single-issue movement (Figure 1). They also show how MBL politicized the movement (Figure 2), transforming it into an anti-corruption movement positioned against president Dilma Rousseff.

Keywords: social participation, June 2013, change in the pattern of association, conservative movements

\title{
Resumo
}

Participação na democracia brasileira: a hegemonia popular e a inovação do protesto da classe média

O Brasil se tornou uma referência na participação social após o sucesso do orçamento participativo no início dos anos 1990. A teoria padrão do sucesso da participação aponta seu impacto positivo sobre o sistema político. No entanto, o Brasil tem experimentado algumas mudanças importantes no nível tanto de participação como de representação desde 2013. No que diz respeito à representação, o fortalecimento das forças conservadoras no Congresso está ocorrendo devido a um aumento no financiamento privado. Estamos vendo também que a participação por si só não pode mudar a composição do sistema de representação. O Brasil atraiu a atenção mundial de eventos ocorridos em junho de 2013, o que causou mudanças nos padrões de participação social. O objetivo deste artigo é analisar as mudanças no Brasil e apontar como elas influenciaram o sistema político do país e afetaram a organização da democracia brasileira. Os dados mostram a forma como 0 MPL 
apresentou as suas demandas sem politizá-las (Figura 1) e como o MBL politizou as demandas feitas em junho de 2013 (Figura 2) organizando um movimento contra a corrupção e contra a presidente Dilma Rousseff.

Palavras-chaves: participação social; junho 2013; mudança no padrão de associação; movimentos conservadores

\section{Resumen}

Participación en el Brasil democrático: la hegemonía popular y la innovación de la protesta de clase media

Brasil se ha convertido en una referencia en lo que respecta a la participación social luego del éxito del presupuesto participativo en los inicios de los años noventa. La teoría más difundida sobre el éxito de la participación destaca su impacto positivo en el sistema político. Sin embargo, Brasil ha experimentado algunos cambios importantes tanto en el nivel de la participación como en el de la representación desde 2013. Por un lado, con respecto a la representación, ha tenido lugar un fortalecimiento de fuerzas conservadoras en el Congreso, debido a un enorme aumento del financiamiento privado. Se observa también que la participación no puede por sí sola transformar la composición del sistema de representación. Por otro lado, Brasil ha atraído la atención del mundo entero por los acontecimientos ocurridos en junio de 2013, que produjeron cambios en los patrones de participación social. El propósito de este artículo es analizar ambos cambios en Brasil y mostrar cómo los mismos han influido en el sistema político del país e impactado en la organización de la democracia brasileña. Los datos muestran como el MPL presentó sus demandas sin politizarlas (Figura 1) y como el MBL politizó las demandas hechas en junio del 2013 (Figura 2) transformándolas en un movimiento contra la corrupción y contra la presidente Dilma Rousseff.

Palabras clave: participación social, junio de 2013, cambio en el patrón de asociación, movimientos conservadores

\section{Résumé}

Participation à la démocratie brésilienne: I'hégémonie populaire et l'innovation de la protestation de la classe moyenne

Le Brésil est devenu une référence dans la participation sociale après le succès du budget participatif pendant le début des années 1990. La théorie traditionnelle sur le succès de la participation indique son effet positif sur le système politique. Cependant, le Brésil a connu quelques changements importants soit au niveau de la participation, soit au niveau de la représentation dès 2013. En ce qui concerne la représentation, le renforcement des forces conservatrices au Congrès se déroule en raison d'une augmentation considérable des financements privés. On constate également que la participation seule ne peut pas changer la composition du système de représentation. Le Brésil a attiré l'attention du monde entier à la suite des événements survenus en juin 2013, qui ont entraîné des changements dans les schémas de participation sociale. L'objectif de cet article est d'analyser ces deux changements au Brésil et d'indiquer comment ils ont influencé le système politique du pays et ont affecté l'organisation de la démocratie brésilienne. Les données montrent de quelle façon le MPL a présenté ses demandes sans les politiser (Figure 1) et comment le MBL a politisé les demandes faites en juin 2013 (Figure 2) organisant alors un mouvement contre la corruption et contre la présidente Dilma Rousseff.

Mots-clés: participation sociale; juin 2013; changement dans le modèle d'association; mouvements conservateurs

Article submitted for publication on January 27, 2016.

Final version approved on December 20, 2017. 